VISION: Journal of Indian Taxation Volume 4, Issue 2, Jul-Dec 2017, pp. 39-63 doi: 10.17492/vision.v4i02.11778

\title{
Sigma and Beta Convergence in Revenues and Expenditure across Indian States
}

\author{
Dirghau Keshao Raut*
}

\begin{abstract}
Applying the idea of convergence in economics to revenues and expenditures of state governments (sub-national governments), the paper examines fiscal convergence across states in India. Using panel and cross-section regressions, the study finds evidence of convergence in revenues and expenditures. Among the fiscal indicators used in the paper, the speed of beta convergence was found to be highest in capital outlay. We contribute to the existing literature by examining the process of convergence in revenues and expenditures for pre and post fiscal rule (FRBM) period which revealed that, the convergence was more pronounced in the post-FRBM period. Evidence of the favourable impact of fiscal rules on indicators such as capital outlay suggest that states should follow fiscal rules for fiscal consolidation without compromising on the quality of expenditure.
\end{abstract}

Keywords: Panel data models; Fiscal policy; State government revenues; State government expenditures; Convergence.

\subsection{Introduction}

The socio-economic equality being an important aspect of development has been emphasised by social reformers and economists across time and space. Disparities in social and economic progress between rural and urban areas, across states and districts, however, has been one of the major problems facing the Indian economy. Citing an example of literacy rate as per Census 2011, Kerala had the highest literacy ratio of 93.9 per cent as compared to the national average of 74 per cent, while Bihar had the lowest literacy ratio of 63.8 per cent. Similarly, the incidence of poverty was 8.3 per cent in Punjab and 33.7 per cent in Bihar as compared to the national average of 21.9 per cent

\footnotetext{
*Assistant Adviser, Department of Economic and Policy Research, Reserve Bank of India, Mumbai, Maharashtra, India. (Email id: dkraut@rbi.org.in)

Disclaimer: The views expressed in the paper are those of author and not of the organisation to which he belongs.
} 
(Government of India, 2013). In addition to disparities in terms of social development indicators, there could be inequalities in infrastructure facilities across states such as access to education, healthcare services, and availability of power and public transportation, which do not only affect employment and investment opportunities, but also lead to uneven human and economic development. The progress of human development in terms of human development index (HDI) also exhibit inequality across states. For example, HDI of Bihar, Odisha and Chhattisgarh (HDI value 0.367, 0.362 and 0.358 , respectively) was much lower compared to Kerala, Punjab and Maharashtra (HDI value $0.790,0.605$ and 0.572 , respectively) in 2007-08 (Government of India, 2011). Though over the years, there has been an improvement in terms of various development indicators in most of the states, the disparities among them are still evident.

Inequalities in socio-economic infrastructure leads to migration of population from less developed to relatively developed states while investment flows to states having better infrastructure resulting in further regional imbalance in economic growth and human development. Therefore, emphasis on balanced growth by extending benefits of development to less developed regions has been one of the major objectives of planned economic development in India. Although the geographical characteristics of the region cannot be changed, discretionary public policies oriented towards creation of social and economic infrastructure in less developed regions can contribute to a more balanced development across the country. In this context, fiscal policy at the state level can play an important role in achieving regionally balanced growth. Both taxation and expenditure policies influence the availability of socio-economic services and also the level of public and private investment.

Recognising the unwavering importance of taxation and expenditure policies, the theoretical and empirical literature shows that variations in economic growth of a state can be explained by its tax burden relative to taxes in other states (Scully, 1991) and the expenditure or provision of public goods is also a widely accepted determinant of economic growth. In the Indian context, Jain and Kumar (2013) in their work on expenditure multipliers found higher size of multiplier for expenditure of state governments than that of the Central Government which highlights the importance of states' fiscal policy especially expenditure policy for achievement of regionally balanced growth. This study also found relatively higher multiplier for capital expenditure. Given this backdrop, it is evident that variations in fiscal policies of states can lead to variations in their economic growth.

The fiscal indicators reveal significant variations in per capita tax revenues and expenditures across states ${ }^{1}$. This is attributable to differences across states in tax base, tax rates, cost of providing socio-economic services and population growth. Apart from 
varying revenue and expenditure patterns ${ }^{2}$, tax-GSDP and expenditure-GSDP ratios also differ across states $^{3}$. In this scenario, fiscal transfers recommended by the Finance Commission play an important role in narrowing inter-state differences in revenues as these transfers help relatively low revenue states to improve services provided by them. Also, given the regional economic imbalances, both Central and State Governments have made efforts for even development of states/regions. For example, some of the hilly and bordering states have been classified as special category states and are eligible for higher fiscal transfers from the Central Government. This may be one of the reasons for the transition taking place in recent years such as higher GSDP growth in some low income states than the relatively high income states ${ }^{4}$. Nevertheless, there are large variations across states in per capita income $\mathrm{e}^{5}$ (PCI), per capita public expenditure and tax revenues.

Given these variations, convergence in revenue and expenditure indicators across states is called for. The concept of convergence is used mainly in the context of PCI. As per the convergence hypothesis, PCI of poorer economies grow at a faster rate than that of richer economies which results in convergence of PCI among the economies. There are two types of convergence viz., absolute and conditional. In the process of absolute convergence, the countries/regions having different initial PCI converge to same steady-state PCI over a period of time assuming similarity of other factors across countries/regions that affect growth of PCI. In case of conditional convergence, countries or regions converge to a different steady state point when other factors influencing PCI are also considered. This paper finds fiscal convergence in terms of revenue and expenditure indicators across states which has been more pronounced in the post-FRBM period.

The rest of the paper is organised into five sections. The survey of empirical literature on convergence is covered in section 2. Stylized facts based on trend in fiscal indicators pointing towards declining dispersion across states are provided in section 3 . Section 4 describes the data and the methodology used, while empirical results of sigma and beta convergence are presented in section 5. Concluding observations and policy implications are given in section 6.

\subsection{Review of Literature}

In the literature, the term 'convergence' is referred to in the context of income/growth convergence. The convergence hypothesis has been applied to assess the disparities in socio-economic indicators, primarily PCI, across countries, regions, provinces, districts and cities. The Solow and Swan growth model (1956) states that countries with less capital per worker will have higher marginal product, leading to flow 
of investment from rich to poor countries till capital and output per worker converge across countries. Baumol (1986) found convergence in GDP per work-hour during 18701979 among 16 industrialised countries. Barro and Martin (1991) found convergence in PCI and gross state product of the States in U.S. According to them, PCI of poorer states grows at a faster rate than that of richer states; the annual convergence speed being 2 per cent. Similar pattern of convergence was observed in the western European countries. In the Indian context, many studies have examined income convergence across states (Cherodian et al. 2013; Bandyopadhyay 2011; Rangarajan et al. 2014). These studies generally observed that there was no evidence of absolute convergence in income across states $^{6}$.

In fiscal policy, the convergence hypothesis has been applied in the context of revenues and expenditures of governments across countries and regions/provinces/states. According to Tiebout (1956), municipalities within a region provide different government services at different prices (tax rates), and due to varying preferences individuals will move to the local community which maximises their utility. Coughlin et al. (2006) examined convergence in tax revenues and expenditures of state and local governments in 48 contiguous states of the U.S. and observed that fiscal policies are converging. Saruc et al. (2007) studied convergence process of tax revenues and public expenditures across Turkish provinces using sigma and beta convergence methods ${ }^{7}$. Though they did not find evidence on sigma convergence, beta convergence in public expenditure was observed.

In the Indian context, Mohanty (2011) studied sigma convergence, beta convergence and spatial convergence in public revenue, public expenditure and PCI across 14 non-special category states. The author concluded that the absence of convergence in public revenues and public expenditures is deterrent to sustainable economic growth of the Indian economy. Sethi et al. (2012) analysed the convergence in public expenditure on various items, HDI and PCI by estimating sigma and beta convergence across 17 Indian states for the period 1985-2006. The results of their study revealed no beta convergence but strong sigma convergence for aggregate per capita expenditure, and strong sigma and beta convergence in expenditure on 'social and community services' and 'education, sports, art and culture'. Their analysis also gave evidence of convergence in HDI and divergence in PCI of states. Garg (2015) examined implications of federal transfers in convergence of real per capita expenditure in four categories viz., aggregate, development, education and health, across 14 states. Using the panel fixed effect model, spatial auto-regressive model and spatial error model, conditional convergence was observed in all four expenditure categories with federal 
transfers helping convergence wherein speed of convergence was higher in formula transfers as compared with discretionary transfers.

As per the RBI's 'State Finances: A Study of Budgets of 2010-11', transfers recommended by FCs have been progressive as FCs followed horizontal equity principle while recommending transfers. Consequently, lower fiscal capacity states received a higher transfers and vice versa. Further, the report also mentioned that greater emphasis on fiscal capacity distance and fiscal discipline by the Thirteenth FC would facilitate greater convergence among the states.

This paper makes contribution to the existing literature on fiscal convergence among Indian states across different dimensions. First, it examines convergence in fiscal policy of states comprehensively by considering all major fiscal indicators such as states' own tax and non-tax revenues, fiscal transfers, revenue expenditure, capital outlay and social sector expenditure which are better representative of state fiscal policy as compared to earlier studies (Mohanty, 2011; Garg, 2015 and Sethi et al., 2012). Second, this study examines convergence across 25 states $^{8}$, as against earlier studies of Mohanty (2011) and Garg (2015) for 14 states and Sethi et al. (2012) for 17 states. Third, it studies fiscal convergence by comparing the results for pre and post-FRBM periods and also using the dummy for FRBM years which has not been attempted in earlier studies. Fourth, this paper uses beta convergence method in both cross section and panel data framework along with empirical estimation of sigma convergence by regressing coefficient of variation $(\mathrm{CV})$ of fiscal indicators over time.

\subsection{Stylised Facts}

Long-term trends in the fiscal performance of states reveal that state finances started deteriorating in 1987-88 which continued through the 1990s. The implementation of pay commission awards and the losses of state public undertakings were the prominent factors leading to higher fiscal deficits and debt levels which peaked in 200304. However, due to various fiscal reforms at the state level, there has been improvement in state finances since mid-2000s (Table 1).

The revenue account witnessed a turnaround from deficit to surplus at the consolidated level since mid-2000s. The improvement in revenue account was contributed by both revenues and expenditures. Notably, the improvement in fiscal position was not limited to a particular state. With revenue account turning into surplus, fiscal deficit-GSDP and debt-GSDP ratios moderated across most of the states since 2005-06. The fiscal consolidation was facilitated by measures at the national level such as higher fiscal transfers, debt swap scheme (DSS) ${ }^{9}$, debt consolidation and relief facility 
supplemented by state level initiatives including the implementation of FRBM Act and tax reforms viz., the introduction of value added tax (VAT) besides efforts to increase tax base and improve efficiency in tax collections.

Table 1: Key Fiscal Indicators of States (per cent of GDP)

\begin{tabular}{|c|c|c|c|c|c|}
\hline Item & 1990s & $2000 s$ & 2000-05 & 2005-10 & 2010-15 \\
\hline & \multicolumn{5}{|c|}{ (Average) } \\
\hline Revenue Deficit & 1.2 & 1.0 & 2.2 & -0.2 & -0.2 \\
\hline Gross Fiscal Deficit & 3.0 & 3.1 & 3.9 & 2.2 & 2.2 \\
\hline Outstanding Debt & 21.6 & 28.9 & 30.1 & 27.6 & 22.4 \\
\hline \multicolumn{6}{|c|}{ Votes: 1. Negative sign '-’ indicates surplus. } \\
\hline \multicolumn{6}{|c|}{$\begin{array}{l}\text { 2. GDP data used for calculating averages of ratios are based on old series (2004-05) from 1990-91 } \\
\text { to 2010-11 and new series (2011-12) from 2011-12 to 2014-15. }\end{array}$} \\
\hline
\end{tabular}

Revenue expenditure-GDP ratio of states generally experienced a declining trend since mid-2000s which emanated mainly from decline in committed expenditure. Within committed expenditure, the interest payments-GSDP ratio moderated across states reflecting the impact of decline in debt-GSDP ratio, interest rate benefits arising from higher share of relatively low cost market borrowings in financing fiscal deficit and DSS which was implemented during 2002-03 to 2004-05. Consequently, the revenue account position improved, allowing states to spend more on growth-oriented capital expenditure. This was mirrored in the compound annual growth rates (CAGR) of total expenditure, capital outlay and social sector expenditure during 1995-2015 vis-à-vis those during 1995-96 (Chart 1). This also indicates that the states having low per capita expenditure in 1995-96 recorded higher expenditure growth in these expenditure categories during 1995-2015 as compared to the states having high per capita expenditure in 1995-96.

Within revenue receipts, the initial level of per capita own tax revenues (OTR) in 1995-96 and CAGR of per capita OTR during 1995-2015 moved in opposite direction. Similar trend was noticed in the case of own non-tax revenues (ONTR), share in Central taxes (SCT) and grants from the Centre (Chart 2). These preliminary trends indicate narrowing down of disparities in fiscal indicators across states which can be validated empirically by testing convergence hypothesis using sigma and beta convergence methods. 
Chart 1: Compound Annual Growth Rate (1995-2015) - Expenditure Items
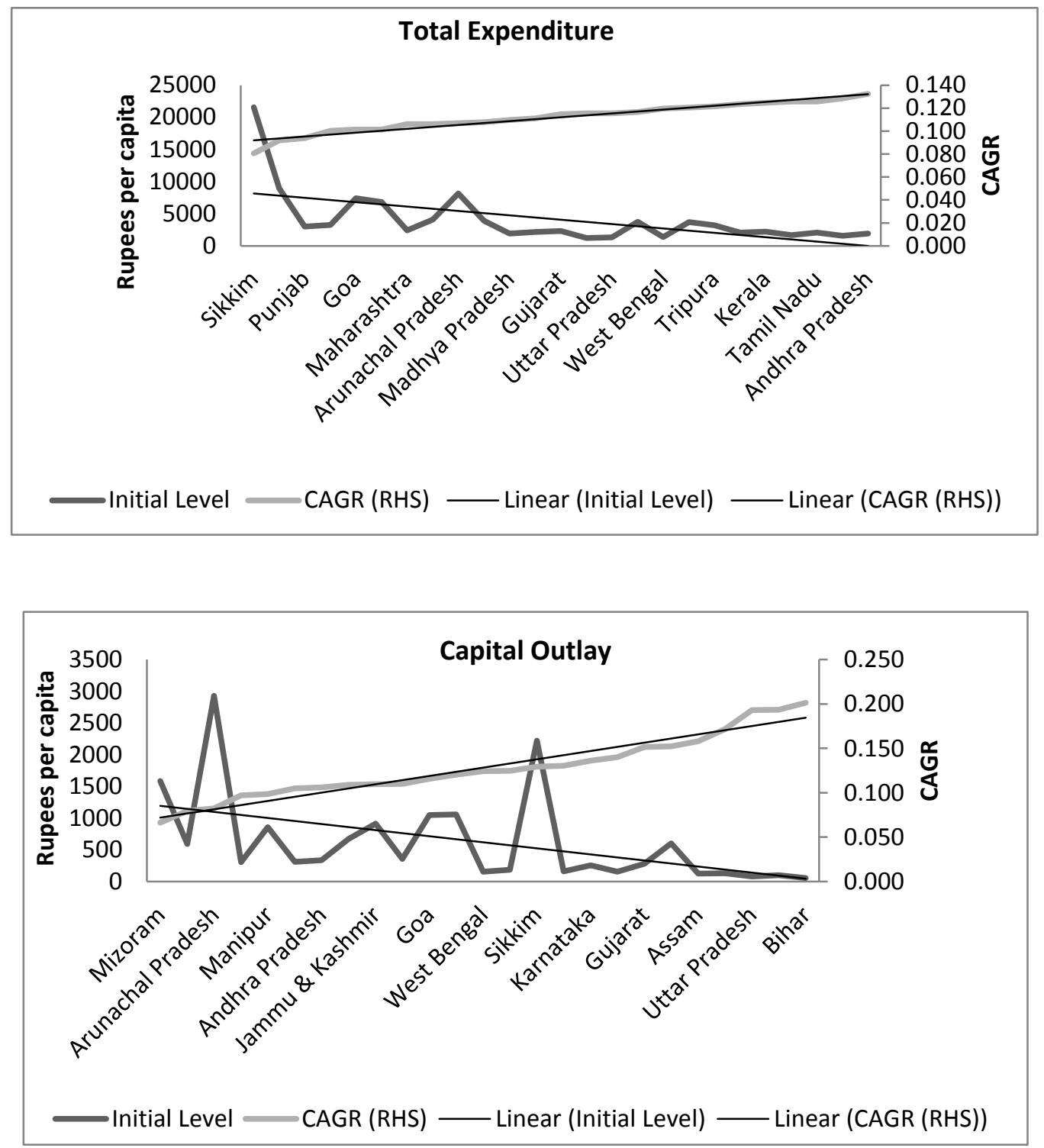
46 | VISION: Journal of Indian Taxation, Volume 4, Issue 2, Jul-Dec 2017

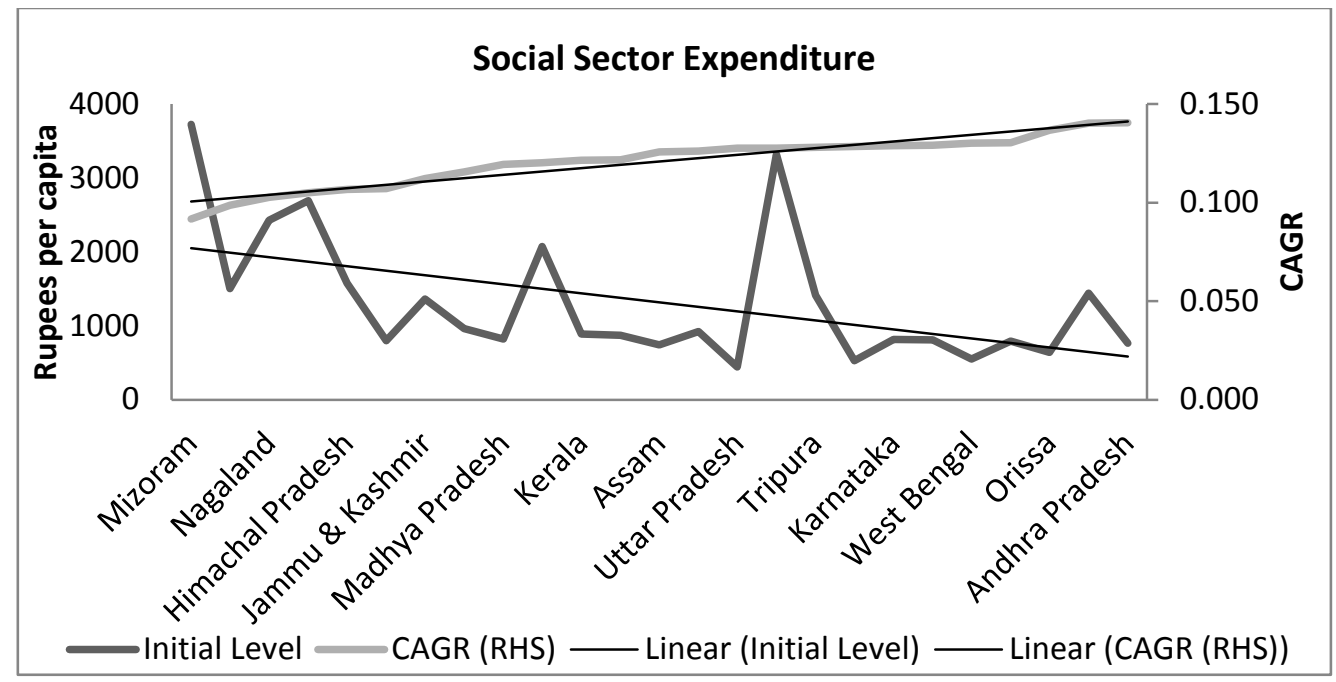

Note: States have been arranged in ascending order according to their CAGR of per capita expenditures. Source: State Finances: A Study of Budgets (various issues) and author's calculations.

\section{Chart 2: Compound Annual Growth Rate (1995-2015) - Revenue Receipts}

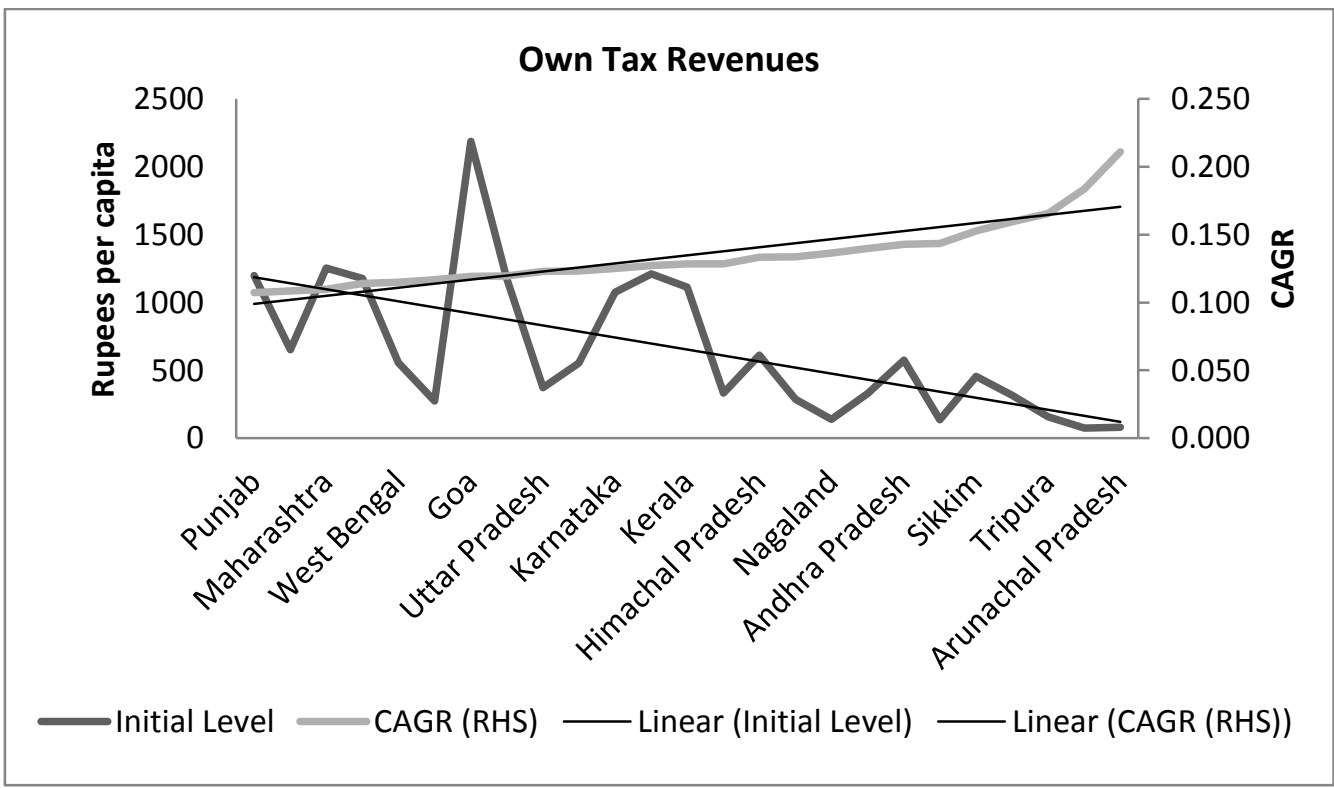



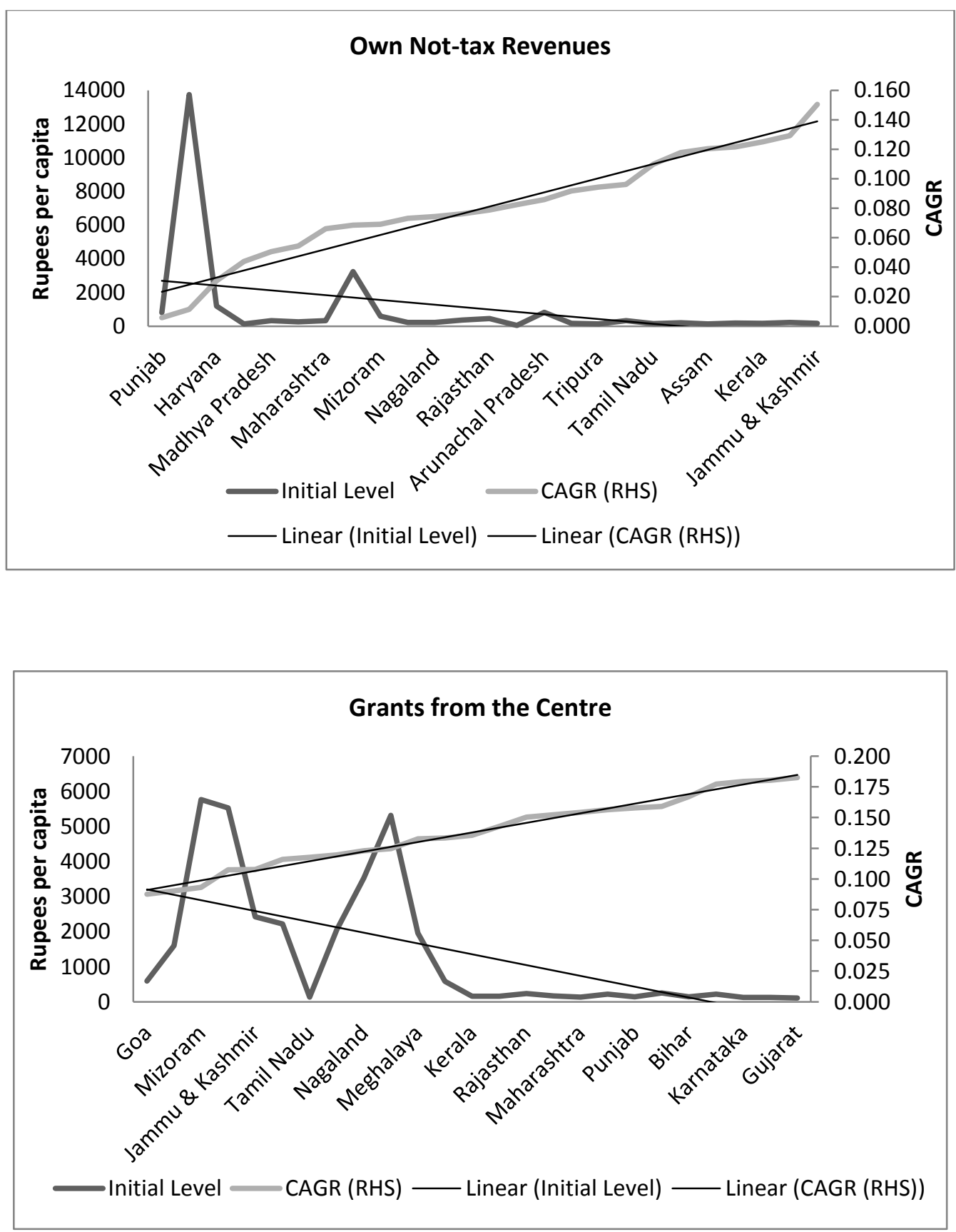


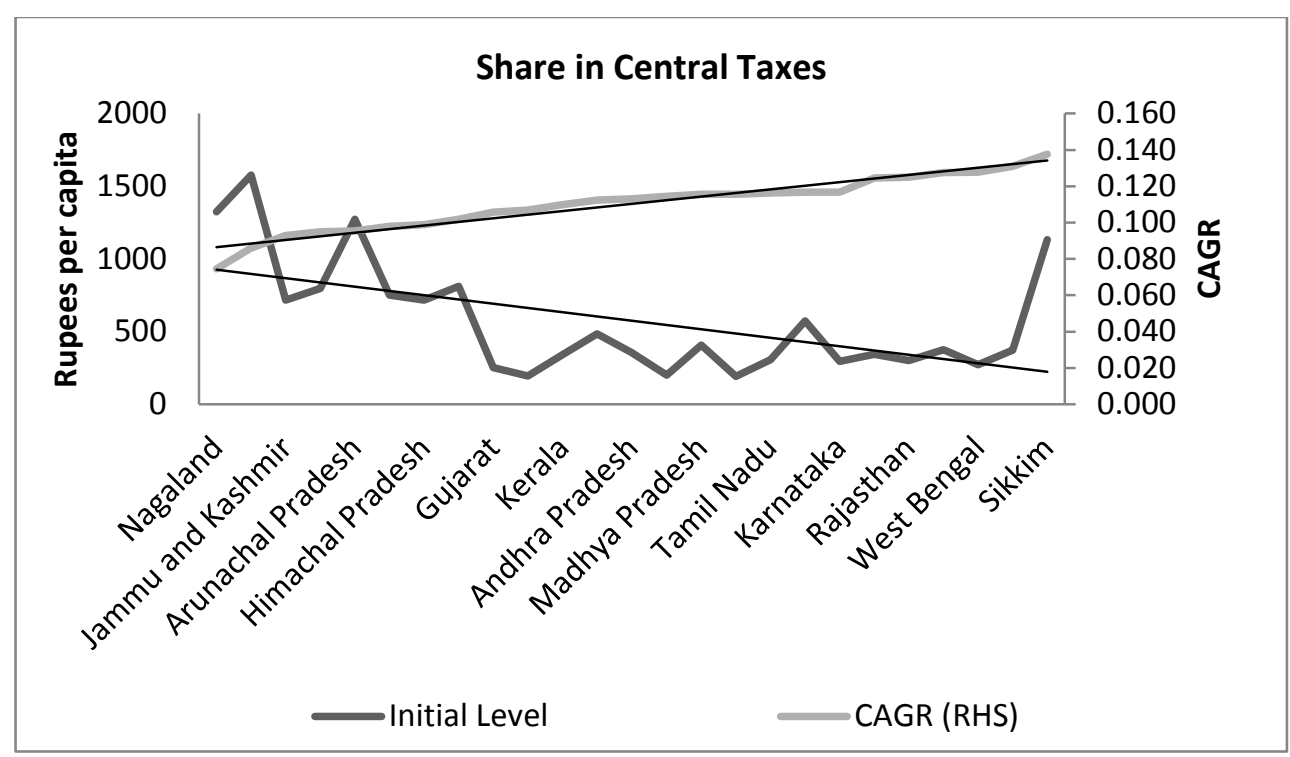

Note: States have been arranged in ascending order according to their CAGR of per capita revenues. Source: State Finances: A Study of Budgets (various issues) and author's calculations.

\subsection{Data and Methodology}

The period covered in this paper is $1995-96$ to $2014-15^{10}$ which ensures that the period since the implementation of FRBM Act (from 2005 onwards) by majority of states is comparable with the period before FRBM Act. This study is based on data pertaining to 25 states. The selection of 25 states (Chhattisgarh, Jharkhand and Uttarakhand are excluded) allows to have consistent data points over the time period of study. Population data are sourced from Central Statistics Office (CSO $)^{11}$.

To capture fiscal policy of states, major indicators of both revenues and expenditures have been used. Revenue indicators used in this paper include total revenue receipts, own revenues (both tax and non-tax) and fiscal transfers (grants and share in central taxes). On the expenditure side, total expenditure, revenue expenditure, capital outlay, committed expenditure ${ }^{12}$ and social sector expenditure ${ }^{13}$ have been covered. Both revenue and expenditure data are sourced from State Finances: A Study of Budgets for various years and Handbook of Statistics on State Government Finances 2010, published by the Reserve Bank of India. This study examines both sigma and beta convergence in fiscal indicators. The sigma convergence method is used to measure the reduction/increase in disparity across cross-section over a period of time. It is generally analysed by comparing standard deviation or CV across cross-sections over a period. If 
the standard deviation or $\mathrm{CV}$ of the fiscal indicator is declining over time, it indicates sigma convergence. The sigma convergence can also be examined through regression method by regressing $\mathrm{CV}$ of a fiscal indicator over time.

$$
Y_{t}=a+b X_{t}+u_{t}
$$

Here $Y_{t}$ is $\mathrm{CV}$ of fiscal indicator i.e., per capita revenue or expenditure, $a$ is constant term, $b$ is slope coefficient, $\mathrm{X}$ is linear time trend in years $(\mathrm{t}=1,2, \ldots \mathrm{n})$ and $u_{t}$ is the error term. According to this method, if the value of $b$ is less than 0 and statistically significant, it indicates convergence.

Beta convergence is said to occur if the countries/states/regions having initially low PCI (in this study it is fiscal indicator i.e. per capita revenue or expenditure) grow at a faster rate than those having higher PCI. The beta convergence method is based on econometric modeling and it also measures the speed of convergence. To obtain evidence with regard to beta convergence, the growth of PCI is regressed upon its initial level. As per this method, convergence is confirmed if the coefficient of initial level of PCI is negative and statistically significant. In this study, cross-section ordinary least square (OLS), panel unit root test and panel data estimated generalized least square (EGLS) estimation have been applied to obtain empirical evidence on beta convergence. The following cross-section estimation introduced by Baumol (1986) for beta convergence, which is widely used in the convergence literature, is estimated in this study.

$$
\frac{1}{T} \ln \left(\frac{Y_{i T}}{Y_{i 0}}\right)=\alpha+\beta \ln \left(Y_{i 0}\right)+\varepsilon_{i}
$$

Where $\mathrm{T}$ is length of time interval, $\mathrm{ln}$ is natural logarithm, $Y_{i T}$ is the fiscal indicator i.e. per capita revenue or expenditure of state ' $i$ ' in terminal year of time period of study and $Y_{i 0}$ is the fiscal indicator of state ' $i$ ' at the beginning of time period, $\alpha$ is constant term, $\beta$ is slope coefficient and $\varepsilon$ is error term. In the cross-section method of beta convergence, the dependent variable is average growth (calculated as cumulative growth of fiscal indicator in the terminal year divided by number of years). As the terminal year could be abnormal year and the results obtained may not give the true evidence of convergence or divergence, this paper also uses panel data framework. The panel framework is being used by researchers extensively to test beta convergence since the work of Islam (1995). In case of the panel data, EGLS estimation is used in this study; the dependent variable is growth in each year of the time period of the study over the initial year. The following basic panel data equation can be used for estimating beta convergence.

$$
\ln \left(\frac{Y_{i t}}{Y_{i 0}}\right)=\alpha+\beta \ln Y_{i 0}+u_{i t}
$$


Here, $\mathrm{Y}$ is the fiscal indicator, $\ln$ is natural logarithm, ' $i$ ' stands for state, ' $t$ ' is time $(t=1,2, \ldots . n)$, ' 0 ' is the initial year of time period. In order to analyse the impact of fiscal policy adopted during the post-FRBM period, a comparison of convergence/divergence between the post-FRBM period vis-à-vis the pre-FRBM period was made by estimating convergence hypothesis separately for 1995-2005 and 20052015. Further, a dummy variable taking value 1 in FRBM years and 0 otherwise, is included in the model to know the role played by fiscal rules in influencing the growth of fiscal indicator. At the same time, it is also recognised that there could be persistence in state's expenditure due to higher share of committed expenditure and also due to the continuance of recurring components of expenditure such as plan expenditure under the five-year plans. Furthermore, the resources to meet these expenditures may not deviate much from the previous year. In view of this, lagged dependent variable to capture persistence of fiscal stance is included in the panel data EGLS estimation. Therefore, the estimated panel data equation with lagged dependent variable and FRBM dummy is as below:

$$
\ln \left(\frac{Y_{i t}}{Y_{i 0}}\right)=\alpha+\beta_{1} \ln Y_{i 0}+\beta_{2} \ln \left(\frac{Y_{i t-1}}{Y_{i 0}}\right)+D U M F R B M_{i t}+u_{i t}
$$

where $\left(\ln \frac{Y_{i t-1}}{Y_{i 0}}\right)$ is the natural logarithm of growth in a fiscal indicator in the previous year over its initial level, $\beta_{1}$ and $\beta_{2}$ are slope coefficients, and DUMFRBM is the dummy used to capture the effect of implementation of FRBM Act by the state. Thus, the panel framework used in this paper controls for persistence of fiscal stance through lagged dependent variable and fiscal rules thorough a dummy variable ${ }^{14}$. Given the problem of heteroscedasticity which is very common in cross-sectional data, panel data EGLS estimation is used to estimate beta convergence. Since the estimation as per equation (4) includes lagged dependent variable, Durbin-Watson h statistic for panel data as generalized by Alok Bhargava et al. (1982) is calculated.

Panel unit root test has been used widely in empirical literature on beta convergence after the work by Evans et al. (1996). In the Indian context, a study by Mukhopadhyay et al. (2014) used panel unit root test to estimate beta convergence in foodgrains production across Indian states. The procedure for estimation of beta convergence using panel unit root test is as below:

$\Delta \tilde{y}_{i t}=\mu_{i}+\rho \tilde{y}_{i, t-1}+\varepsilon_{i t}$

Here, $\tilde{y}_{i t}=y_{i t}-\bar{y}_{t}$ and $\bar{y}_{t}$ is the average value of 'log of fiscal indicator' (per capita) across states in a particular year.

$y_{i t}$ is the log of per capita fiscal indicator of state ' $\mathrm{i}$ ' in time ' $\mathrm{t}$ '. Null hypothesis under this procedure is $\rho=0$. Thus, the rejection of null hypothesis indicates that $\Delta \tilde{y}_{i t}$ as 
stationary series i.e. mean reverting which indicates beta convergence. In this procedure $\mu_{i}=0$ refers to absolute convergence. To examine beta convergence through above panel unit root procedure (equation 5), panel unit root test of Levin, Lin and Chu (2002) and Breitung (2000) have been estimated. Both Levin, Lin and Chu (LLC) and Breitung test assumes common unit root process, and the null hypothesis in both these tests is 'there is a unit root'. However, there is a difference between these two tests in terms of constructing the standardised proxies of $\Delta \tilde{y}_{i t}$ as the LLC test removes both autocorrelations and deterministic components, only autoregressive portion is removed in the Breitung test.

\subsection{Empirical Results}

\subsection{Sigma convergence}

As stated earlier, sigma convergence can be examined by looking at crosssection dispersion measured by standard deviation, $\mathrm{CV}$ or by regressing $\mathrm{CV}$ over time. In beta convergence, fiscal indicator i.e. per capita revenue or expenditure of a state having low initial level will grow at a faster rate than that of a state with high initial level. Thus, even if fiscal indicator of a state having low level in the initial year grows at a faster rate over a period, the dispersion may not change if the fiscal indicator of the state having high initial level also grows at faster rate ${ }^{15}$. Therefore, the analysis based on sigma convergence becomes important to know the dynamics of disparities over a period of time.

Among the revenue side indicators, all indicators except share in central taxes showed sigma convergence. Within expenditure, total expenditure and revenue expenditure witnessed sigma convergence, while results for other expenditure categories such as capital outlay, social sector expenditure and committed expenditure were inconclusive (Table 2). The findings on sigma convergence in total expenditure are in line with an earlier study in the Indian context (Sethi et al. 2012).

A comparison of sigma convergence in the post-FRBM period with the preFRBM period revealed differences such as convergence in social sector expenditure, and divergence in capital outlay and share in central taxes during the post-FRBM period. The divergence in the case of share in central taxes is indicative of the differences in fiscal capacities/income distance of states which is the main criterion with largest weight for distribution of tax devolution among the states. 
52 | VISION: Journal of Indian Taxation, Volume 4, Issue 2, Jul-Dec 2017

Table 2: Sigma Convergence

\begin{tabular}{|c|c|c|c|c|c|c|c|c|c|}
\hline \multirow{2}{*}{$\begin{array}{c}\text { Depende } \\
\text { nt } \\
\text { variable }\end{array}$} & \multicolumn{3}{|c|}{$1995-2015$} & \multicolumn{3}{|c|}{ 1995-2005 } & \multicolumn{3}{|c|}{ 2005-15 } \\
\hline & constant & $\begin{array}{l}\text { slope } \\
\text { coefficie } \\
\text { nt }\end{array}$ & $\begin{array}{c}R^{2} \\
\mathrm{D}-\mathrm{W}\end{array}$ & Constant & $\begin{array}{l}\text { slope } \\
\text { coefficient }\end{array}$ & $\begin{array}{c}R^{2} \\
\mathrm{D}-\mathrm{W}\end{array}$ & constant & $\begin{array}{l}\text { slope } \\
\text { coefficient }\end{array}$ & $\begin{array}{c}R^{2} \\
\mathrm{D}-\mathrm{W}\end{array}$ \\
\hline \multirow[t]{2}{*}{ CV_TE } & $1.07^{*}$ & $-0.02 *$ & 0.70 & $1.13^{*}$ & $-0.03^{* *}$ & 0.42 & $0.82^{*}$ & $-0.01^{*}$ & 0.76 \\
\hline & (26.08) & $(-6.49)$ & 2.11 & (13.43) & $(-2.45)$ & 2.33 & $(42.52)$ & $(-5.09)$ & 2.60 \\
\hline \multirow[t]{2}{*}{ CV_CO } & $1.04 *$ & -0.005 & 0.13 & $1.06^{*}$ & -0.00 & 0.05 & $0.87^{*}$ & $0.01 * * *$ & 0.34 \\
\hline & (28.48) & $(-1.64)$ & 1.34 & (21.79) & $(-0.68)$ & 1.09 & (19.42) & (2.03) & 2.94 \\
\hline \multirow[t]{2}{*}{ CV_RE } & $1.15^{*}$ & $-0.02 *$ & 0.73 & $1.22 *$ & $-0.04 * *$ & 0.48 & $0.83^{*}$ & $-0.02^{*}$ & 0.88 \\
\hline & (23.57) & $(-7.02)$ & 2.02 & (12.33) & $(-2.73)$ & 2.29 & (47.56) & $(-7.84)$ & 2.69 \\
\hline \multirow{2}{*}{$\begin{array}{c}\text { CV_Co } \\
\text { mm. }\end{array}$} & $0.52 *$ & 0.001 & 0.10 & $0.56^{*}$ & $-0.007 *$ & 0.64 & $0.53^{*}$ & 0.002 & 0.14 \\
\hline & (41.29) & (1.42) & 0.56 & $(48.29)$ & $(-3.83)$ & 0.96 & $(35.82)$ & (1.14) & 1.13 \\
\hline \multirow{2}{*}{$\underset{\mathrm{E}}{\mathrm{SCV} \text { SSS }}$} & $0.66^{*}$ & -0.002 & 0.11 & $0.63^{*}$ & 0.004 & 0.10 & $0.67 *$ & $-0.007 * *$ & 0.49 \\
\hline & (38.72) & $(-1.50)$ & 1.13 & (22.04) & $(0.94)$ & 0.92 & $(40.42)$ & $(-2.78)$ & 2.84 \\
\hline \multirow[t]{2}{*}{ CV_RR } & $1.24 *$ & $-0.02 *$ & 0.72 & $1.26^{*}$ & $-0.03 * * *$ & 0.29 & $0.86^{*}$ & $-0.01^{*}$ & 0.71 \\
\hline & (24.08) & $(-6.85)$ & 2.21 & (11.79) & $(-1.84)$ & 2.37 & (38.34) & $(-4.48)$ & 2.16 \\
\hline \multirow{2}{*}{$\underset{\mathrm{R}}{\mathrm{CV} O \mathrm{OT}}$} & $0.81^{*}$ & $-0.007^{*}$ & 0.80 & $0.81^{*}$ & $-0.008^{*}$ & 0.72 & $0.78^{*}$ & $-0.01^{*}$ & 0.87 \\
\hline & (73.73) & $(-8.56)$ & 1.01 & (73.53) & $(-4.55)$ & 2.38 & (61.7) & $(-7.49)$ & 1.60 \\
\hline \multirow{2}{*}{$\begin{array}{c}\mathrm{CV}_{\mathrm{TR}} \mathrm{ON} \\
\mathrm{TR}\end{array}$} & $3.20^{*}$ & $-0.08 *$ & 0.76 & $3.15^{*}$ & -0.07 & 0.27 & $2.43 *$ & $-0.10^{*}$ & 0.92 \\
\hline & $(23.97)$ & $(-7.73)$ & 2.42 & (11.1) & $(-1.73)$ & 2.46 & (36.99) & $(-9.66)$ & 2.49 \\
\hline \multirow{2}{*}{$\mathrm{CV}_{\overline{\mathrm{V}}} \mathrm{OR}$} & $1.98^{*}$ & $-0.06 *$ & 0.82 & $2.03 *$ & -0.07 *** & 0.42 & $1.26^{*}$ & $-0.05^{*}$ & 0.93 \\
\hline & (22.44) & $(-9.07)$ & 2.30 & (10.65) & $(-2.43)$ & 2.34 & (36.79) & $(-10.50)$ & 2.14 \\
\hline \multirow[t]{2}{*}{ CV_GR } & $1.34^{*}$ & $-0.005^{*}$ & 0.36 & $1.32 *$ & 0.001 & 0.02 & $1.22 *$ & 0.004 & 0.10 \\
\hline & (67.14) & $(-3.20)$ & 1.16 & (67.95) & $(0.45)$ & 1.78 & $(45.99)$ & $\begin{array}{l}(0.95) \\
\end{array}$ & 1.27 \\
\hline \multirow[t]{2}{*}{ CV_SCT } & $0.69^{*}$ & -0.006 & 0.07 & $0.90 *$ & $-0.05 * *$ & 0.50 & $0.55^{*}$ & $0.009^{*}$ & 0.62 \\
\hline & $(10.01)$ & $(-1.17)$ & 0.75 & $(8.29)$ & $(-2.84)$ & 1.36 & $(34.18)$ & (3.65) & 1.36 \\
\hline \multirow[t]{2}{*}{ CV_CT } & $1.13^{*}$ & $-0.005^{*}$ & 0.35 & $1.12 *$ & -0.00 & 0.01 & $1.00^{*}$ & $0.006^{* * *}$ & 0.31 \\
\hline & $(58.62)$ & $(-3.11)$ & 1.18 & $(50.42)$ & $(-0.26)$ & 2.13 & (49.13) & (1.94) & 1.74 \\
\hline
\end{tabular}

Note: 1. Figures in the parentheses are estimated $t$ values.

2. *,**, ***, indicate significance at 1, 5 and 10 per cent, respectively.

3. D-W indicates Durbin- Watson; 4. CV indicates Coefficient of Variation.

\subsection{Beta convergence}

Beta convergence is examined in cross section OLS estimation (Equation 2), in panel EGLS estimation controlling for lagged dependent variable and dummy for years 
under FRBM Act (Equation 4) and also by estimating panel unit root test (equation 5). Table 3 shows the summary of results of sigma convergence and beta convergence obtained through different estimation methods. Within revenue indicators, convergence in states' own revenues is contributed by both OTR and ONTR. Convergence in OTR may be attributed to tax reforms undertaken by states including the implementation of VAT. Mounting inequality in per capita ONTR and higher GSDP growth across states could have facilitated low ONTR states to generate more revenues ${ }^{16}$ through sources such as dividend and profit, and appropriate user charges on social and economic services. Also, commitments under the FRBM Act to achieve fiscal consolidation necessitated states to explore their revenue potential both from tax and non-tax sources which may have led to higher growth in own revenues by states having lower initial own revenues.

Table 3: Summary of Results under Different Methods/Framework

(Period: 1995-2015)

\begin{tabular}{|l|c|c|c|c|}
\hline \multicolumn{1}{|c|}{ Fiscal Indicators } & \multicolumn{3}{|c|}{ Beta Convergence } & $\begin{array}{c}\text { Sigma } \\
\text { Convergence }\end{array}$ \\
\hline & $\begin{array}{c}\text { Cross Section } \\
\text { OLS }\end{array}$ & Panel EGLS & $\begin{array}{c}\text { Panel Unit Root } \\
\text { Test }\end{array}$ & \\
\hline Total Expenditure (TE) & Convergence & Convergence & Convergence & Convergence \\
\hline Capital Outlay (CO) & Convergence & Convergence & Convergence & Inconclusive \\
\hline $\begin{array}{l}\text { Revenue Expenditure } \\
\text { (RE) }\end{array}$ & Convergence & Convergence & Convergence & Convergence \\
\hline $\begin{array}{l}\text { Committed Expenditure } \\
\text { (Comm.) }\end{array}$ & Inconclusive & Inconclusive & Convergence & Inconclusive \\
\hline $\begin{array}{l}\text { Social Sector } \\
\text { Expenditure (SSE) }\end{array}$ & Convergence & Inconclusive & Convergence & Inconclusive \\
\hline Revenue Receipts (RR) & Convergence & Convergence & Convergence & Convergence \\
\hline $\begin{array}{l}\text { Own tax Revenues } \\
\text { (OTR) }\end{array}$ & Convergence & Convergence & Convergence & Convergence \\
\hline $\begin{array}{l}\text { Own Non-tax Revenues } \\
\text { (ONTR) }\end{array}$ & Convergence & Convergence & Convergence & Convergence \\
\hline Own Revenues (ORV) & Convergence & Convergence & Convergence & Convergence \\
\hline Grants (GR) & Convergence & Convergence & & Convergence \\
\hline $\begin{array}{l}\text { Share in Central Taxes } \\
\text { (SCT) }\end{array}$ & Convergence & Inconclusive & Convergence & Inconclusive \\
\hline Fiscal Transfers (FT) & Convergence & Inconclusive & Convergence & Convergence \\
\hline
\end{tabular}

Note: 1. 'Inconclusive' refers to neither showing convergence nor divergence.

*: LLC test revealed convergence, however, null hypothesis of unit root could not be rejected in Breitung Panel unit root test (Table 7). 
The FRBM Act mandated states to eliminate their revenue deficit within a stipulated time. To do this, most states made efforts to cut down revenue expenditure which was coupled with efforts to improve revenues. Consequently, majority of the states achieved revenue surplus or brought down revenue deficit and larger resources for capital expenditure were made available in the second half of $2000 \mathrm{~s}^{17}$. Revenue expenditure, however, declined mainly due to decline in committed expenditure-GDP ratio of all states at the consolidated level from 5.0 per cent in 2003-04 to 3.9 per cent in 2008-09. The reduction in committed expenditure was contributed mainly by lower interest payments due to reforms such as debt swap scheme and financing of states gross fiscal deficit through market borrowings. Therefore, all categories of expenditure studied in this paper except committed expenditure, have converged. The beta convergence found in total expenditure is contrary to an earlier study in the Indian context (Sethi et al. 2012) which could be due to convergence in total expenditure at higher speed during the post-FRBM period which was not covered fully in the earlier study. Capital outlay converged at a higher speed during the post-FRBM period which contributed to convergence in total expenditure.

The states receiving higher fiscal transfers will be in a position to increase/improve the services provided by them at a faster rate compared to those receiving less transfers if there is similarity of fiscal capacities (before transfers) and absence of cost disabilities across states. Thus, fiscal transfers can play an important role in achieving balanced development among states. In India, fiscal transfers from the Centre to states include grants and share in central taxes. Among states, per capita transfers to special category states have been higher than the non-special category states. However, during 1995-2015 most of the non-special category states recorded higher growth in per capita grants and share in Central taxes compared with special category states (chart 2) leading to beta convergence in both grants and share in central taxes.

The comparison of pre-and post-FRBM period is attempted for beta convergence in both cross-section and panel data EGLS estimation, and also in sigma convergence method (Table 2, 4 and 6). The process of beta convergence/divergence among the fiscal indicators of states was different in the post-FRBM period vis-à-vis that in the preFRBM period. First, as per panel EGLS estimation, 8 out of 12 indicators showed change in their convergence/divergence/inconclusive position in the post-FRBM period vis-à-vis pre-FRBM period. Second, in the post-FRBM period convergence was found in social sector expenditure and ONTR; this result is consistent across methods including the panel EGLS estimation controlling for lagged dependent variable. Third, beta convergence at higher speed for capital outlay is found in the post-FRBM period in both cross-section and panel EGLS estimation. The convergence/higher speed of convergence 
in fiscal indicators could be attributable to efforts made by states to raise their revenues for meeting the fiscal targets envisaged in their FRBM Acts and higher FC transfers. The higher growth in ONTR of states having relatively low initial level of OTNR, measures to improve tax revenues including implementation of VAT and higher transfers may have led to higher revenue growth in states with relatively poor fiscal capacity.

Table 4: Beta Convergence - Cross Section OLS Estimates

\begin{tabular}{|c|c|c|c|c|c|c|c|c|c|}
\hline \multicolumn{4}{|c|}{$1995-2015$} & \multicolumn{3}{|c|}{ 1995-2005 } & \multicolumn{3}{|c|}{$2005-2015$} \\
\hline $\begin{array}{c}\text { Dependent } \\
\text { variable }\end{array}$ & $\alpha$ & $\beta$ & $\begin{array}{c}R^{2} \\
\text { D-W }\end{array}$ & $\alpha$ & $\beta$ & $\begin{array}{c}R^{2} \\
\mathrm{D}-\mathrm{W}\end{array}$ & $\alpha$ & $\beta$ & $\begin{array}{c}R^{2} \\
\mathrm{D}-\mathrm{W}\end{array}$ \\
\hline $\mathrm{TE}$ & $\begin{array}{l}0.20 * \\
(11.29)\end{array}$ & $\begin{array}{l}-0.01^{*} \\
(-5.47)\end{array}$ & $\begin{array}{l}0.56 \\
1.69\end{array}$ & $\begin{array}{l}0.15^{*} \\
(3.91)\end{array}$ & $\begin{array}{l}-0.008 * * * \\
(-1.86)\end{array}$ & $\begin{array}{l}0.13 \\
2.43\end{array}$ & $\begin{array}{l}0.30^{*} \\
(7.33)\end{array}$ & $\begin{array}{l}-0.02 * \\
(-4.38)\end{array}$ & $\begin{array}{l}0.45 \\
1.91\end{array}$ \\
\hline $\mathrm{CO}$ & $\begin{array}{l}0.24 * \\
(10.18)\end{array}$ & $\begin{array}{l}-0.02 * \\
(-5.35)\end{array}$ & $\begin{array}{l}0.55 \\
1.35\end{array}$ & $\begin{array}{l}0.18 \\
(3.33)\end{array}$ & $\begin{array}{l}-0.01 * * * \\
(-1.82)\end{array}$ & $\begin{array}{l}0.12 \\
1.96\end{array}$ & $\begin{array}{l}0.39^{*} \\
(6.89)\end{array}$ & $\begin{array}{l}-0.03 * \\
(-4.60)\end{array}$ & $\begin{array}{l}0.47 \\
1.82\end{array}$ \\
\hline $\mathrm{RE}$ & $\begin{array}{l}0.20^{*} \\
(9.54)\end{array}$ & $\begin{array}{l}-0.01 * \\
(-4.73)\end{array}$ & $\begin{array}{l}0.49 \\
1.44\end{array}$ & $\begin{array}{l}0.15^{*} \\
(3.27)\end{array}$ & $\begin{array}{l}-0.008 \\
(-1.53)\end{array}$ & $\begin{array}{l}0.09 \\
2.23\end{array}$ & $\begin{array}{l}0.30^{*} \\
(7.64)\end{array}$ & $\begin{array}{l}-0.02 * \\
(-4.53)\end{array}$ & $\begin{array}{l}0.47 \\
1.61\end{array}$ \\
\hline Comm & $\begin{array}{l}0.13^{*} \\
(4.20)\end{array}$ & $\begin{array}{l}-0.00 \\
(-0.77)\end{array}$ & $\begin{array}{l}0.02 \\
1.69\end{array}$ & $\begin{array}{l}0.15^{*} \\
(3.07)\end{array}$ & $\begin{array}{l}-0.007 \\
(-0.93)\end{array}$ & $\begin{array}{l}0.03 \\
1.91\end{array}$ & $\begin{array}{l}0.12^{*} \\
(3.31)\end{array}$ & $\begin{array}{l}-0.003 \\
(-0.69)\end{array}$ & $\begin{array}{l}0.02 \\
1.85\end{array}$ \\
\hline SSE & $\begin{array}{l}0.19^{*} \\
(8.15)\end{array}$ & $\begin{array}{l}-0.01 * \\
(-3.40)\end{array}$ & $\begin{array}{l}0.33 \\
2.52\end{array}$ & $\begin{array}{l}0.03 \\
(0.77)\end{array}$ & $\begin{array}{l}0.004 \\
(0.73)\end{array}$ & $\begin{array}{l}0.02 \\
2.15\end{array}$ & $\begin{array}{l}0.35 * \\
(6.79)\end{array}$ & $\begin{array}{l}-0.02 * \\
(-4.04)\end{array}$ & $\begin{array}{l}0.41 \\
2.44 \\
\end{array}$ \\
\hline RR & $\begin{array}{l}0.21 * \\
(12.23)\end{array}$ & $\begin{array}{l}-0.01 * \\
(-6.14)\end{array}$ & $\begin{array}{l}0.62 \\
1.60\end{array}$ & $\begin{array}{l}0.15^{*} \\
(5.29)\end{array}$ & $\begin{array}{l}-0.01 * \\
(-2.77)\end{array}$ & $\begin{array}{l}0.25 \\
2.02\end{array}$ & $\begin{array}{l}0.30^{*} \\
(6.83)\end{array}$ & $\begin{array}{l}-0.02 * \\
(-4.04)\end{array}$ & $\begin{array}{l}0.41 \\
1.81\end{array}$ \\
\hline OTR & $\begin{array}{l}0.23 * \\
(11.99)\end{array}$ & $\begin{array}{l}-0.01 * \\
(-5.59)\end{array}$ & $\begin{array}{l}0.57 \\
1.80\end{array}$ & $\begin{array}{l}0.21 * \\
(5.49)\end{array}$ & $\begin{array}{l}-0.01 * \\
(-2.89)\end{array}$ & $\begin{array}{l}0.26 \\
2.12\end{array}$ & $\begin{array}{l}0.27 * \\
(8.47)\end{array}$ & $\begin{array}{l}-0.02 * \\
(-4.53)\end{array}$ & $\begin{array}{l}0.47 \\
2.10\end{array}$ \\
\hline ONTR & $\begin{array}{l}0.17 * \\
(6.03)\end{array}$ & $\begin{array}{l}-0.01^{*} \\
(-3.43)\end{array}$ & $\begin{array}{l}0.33 \\
2.47\end{array}$ & $\begin{array}{l}0.13 * * \\
(2.27)\end{array}$ & $\begin{array}{l}-0.01 \\
(-1.32)\end{array}$ & $\begin{array}{l}0.07 \\
2.41\end{array}$ & $\begin{array}{l}0.28^{*} \\
(5.06)\end{array}$ & $\begin{array}{l}-0.02 * \\
(-3.42)\end{array}$ & $\begin{array}{l}0.33 \\
2.82\end{array}$ \\
\hline ORV & $\begin{array}{l}0.23^{*} \\
(9.20)\end{array}$ & $\begin{array}{l}-0.01 * \\
(-5.03)\end{array}$ & $\begin{array}{l}0.52 \\
1.86\end{array}$ & $\begin{array}{l}0.16^{*} \\
(3.33)\end{array}$ & $\begin{array}{l}-0.01 \\
(-1.68)\end{array}$ & $\begin{array}{l}0.11 \\
1.98\end{array}$ & $\begin{array}{l}0.32 * \\
(7.92)\end{array}$ & $\begin{array}{l}-0.02 * \\
(-5.10)\end{array}$ & $\begin{array}{l}0.53 \\
1.97\end{array}$ \\
\hline GR & $\begin{array}{l}0.21 * \\
(13.62)\end{array}$ & $\begin{array}{l}-0.01 * \\
(-5.42)\end{array}$ & $\begin{array}{l}0.56 \\
2.59 \\
\end{array}$ & $\begin{array}{l}0.07 * \\
(2.79) \\
\end{array}$ & $\begin{array}{l}-0.00 \\
(-0.09) \\
\end{array}$ & $\begin{array}{l}0.00 \\
2.41 \\
\end{array}$ & $\begin{array}{l}0.32 * \\
(7.50)\end{array}$ & $\begin{array}{l}-0.02 * \\
(-3.97) \\
\end{array}$ & $\begin{array}{l}0.40 \\
1.99 \\
\end{array}$ \\
\hline SCT & $\begin{array}{l}0.17 * \\
(7.70)\end{array}$ & $\begin{array}{l}-0.01^{*} \\
(-3.20)\end{array}$ & $\begin{array}{l}0.30 \\
1.75\end{array}$ & $\begin{array}{l}0.27^{*} \\
(5.32)\end{array}$ & $\begin{array}{l}-0.03 * \\
(-4.27)\end{array}$ & $\begin{array}{l}0.44 \\
1.71\end{array}$ & $\begin{array}{l}0.08 * * \\
(2.05)\end{array}$ & $\begin{array}{l}0.006 \\
(0.96)\end{array}$ & $\begin{array}{l}0.03 \\
2.15\end{array}$ \\
\hline FT & $\begin{array}{l}0.18 \\
*(13.66)\end{array}$ & $\begin{array}{l}-0.009 * \\
(-5.07)\end{array}$ & $\begin{array}{l}0.52 \\
2.14\end{array}$ & $\begin{array}{l}0.09 * \\
(3.93)\end{array}$ & $\begin{array}{l}-0.00 \\
(-0.84)\end{array}$ & $\begin{array}{l}0.03 \\
1.92\end{array}$ & $\begin{array}{l}0.23 * \\
(6.13)\end{array}$ & $\begin{array}{l}- \\
0.01 * * \\
(-2.59)\end{array}$ & $\begin{array}{l}0.22 \\
1.84\end{array}$ \\
\hline
\end{tabular}

Notes: 1. Figures in the parentheses are estimated $t$ values.

2. *, **, ***, indicate significance at 1,5 and 10 per cent, respectively.

3. D-W indicates Durbin- Watson

The higher growth in revenues coupled with reduction in committed expenditure may have contributed to higher speed of convergence in social sector expenditure and capital outlay during the post-FRBM period. However, divergence in capital outlay as 
per sigma convergence method despite beta convergence indicates that the states having high initial level of capital outlay recorded lower growth and vice versa ${ }^{18}$. Fourth, the convergence found in committed expenditure in the pre-FRBM period (beta convergence in panel framework and sigma convergence) could not be sustained during the postFRBM period. This indicates that reduction in committed expenditure was due to decline in interest payments which was broadly similar across states.

The role of fiscal rules captured by dummy variable (as per equation 4) taking value 1 in the FRBM years and 0 otherwise was found to have a significant bearing on growth of all the indicators except committed expenditure (Table 5). Fiscal rules were found supporting revenue augmentation both through states' own sources and transfers.

Table 5: Beta Convergence-Panel EGLS Estimation with FRBM Dummy (Period: 1995-2015)

\begin{tabular}{|c|c|c|c|c|c|}
\hline $\begin{array}{l}\text { Dependent } \\
\text { Variables }\end{array}$ & Constant & Initial level & $\begin{array}{c}\text { Lagged dependent } \\
\text { variable }\end{array}$ & $\begin{array}{c}\text { FRBM } \\
\text { Dummy }\end{array}$ & $\begin{array}{c}R^{2} \\
\text { D-W H } \\
\text { statistic }\end{array}$ \\
\hline $\mathrm{TE}$ & $\begin{array}{l}0.19 * \\
(3.36)\end{array}$ & $\begin{array}{c}-0.01 * * * \\
(-1.78)\end{array}$ & $\begin{array}{c}1.00 * \\
(103.1)\end{array}$ & $\begin{array}{l}0.02 * \\
(2.46)\end{array}$ & $\begin{array}{l}0.98 \\
2.48\end{array}$ \\
\hline $\mathrm{CO}$ & $\begin{array}{l}0.30 * \\
(3.79)\end{array}$ & $\begin{array}{l}-0.03 * * \\
(-2.41)\end{array}$ & $\begin{array}{c}0.90 * \\
(41.34)\end{array}$ & $\begin{array}{l}0.17 * \\
(5.06)\end{array}$ & $\begin{array}{l}0.91 \\
2.15\end{array}$ \\
\hline $\mathrm{RE}$ & $\begin{array}{l}0.18 * \\
(3.25)\end{array}$ & $\begin{array}{c}-0.01 * * * \\
(-1.60)\end{array}$ & $\begin{array}{c}1.00 * \\
(105.3)\end{array}$ & $\begin{array}{l}0.02 * * \\
(2.25)\end{array}$ & $\begin{array}{l}0.98 \\
2.35\end{array}$ \\
\hline Comm. & $\begin{array}{l}0.19 * \\
(4.52) \\
\end{array}$ & $\begin{array}{l}-0.009 \\
(-1.43)\end{array}$ & $\begin{array}{c}0.97 * \\
(116.4)\end{array}$ & $\begin{array}{l}0.004 \\
(0.43)\end{array}$ & $\begin{array}{l}0.98 \\
1.97\end{array}$ \\
\hline SSE & $\begin{array}{l}0.13 * \\
(2.43)\end{array}$ & $\begin{array}{l}-0.007 \\
(-0.91)\end{array}$ & $\begin{array}{c}1.00 * \\
(92.25)\end{array}$ & $\begin{array}{l}0.06^{*} \\
(4.54)\end{array}$ & $\begin{array}{l}0.98 \\
2.19\end{array}$ \\
\hline RR & $\begin{array}{l}0.18^{*} \\
(3.64)\end{array}$ & $\begin{array}{l}-0.01 * * \\
(-2.01)\end{array}$ & $\begin{array}{c}1.00^{*} \\
(107.59)\end{array}$ & $\begin{array}{l}0.05^{*} \\
(4.85)\end{array}$ & $\begin{array}{l}0.98 \\
2.49\end{array}$ \\
\hline OTR & $\begin{array}{l}0.23^{*} \\
(7.48)\end{array}$ & $\begin{array}{l}-0.01 * \\
(-4.06)\end{array}$ & $\begin{array}{c}0.99 * \\
(136.7) \\
\end{array}$ & $\begin{array}{l}0.03 * \\
(2.99)\end{array}$ & $\begin{array}{l}0.99 \\
2.22\end{array}$ \\
\hline ONTR & $\begin{array}{l}0.25^{*} \\
(3.41) \\
\end{array}$ & $\begin{array}{l}-0.03 * \\
(-2.52) \\
\end{array}$ & $\begin{array}{c}0.91 * \\
(42.78)\end{array}$ & $\begin{array}{l}0.13^{*} \\
(4.67)\end{array}$ & $\begin{array}{l}0.90 \\
2.30\end{array}$ \\
\hline ORV & $\begin{array}{l}0.21 * \\
(4.28)\end{array}$ & $\begin{array}{l}-0.02^{*} \\
(-2.42) \\
\end{array}$ & $\begin{array}{c}0.99 * \\
(99.81) \\
\end{array}$ & $\begin{array}{l}0.05^{*} \\
(4.07)\end{array}$ & $\begin{array}{l}0.98 \\
2.41\end{array}$ \\
\hline GR & $\begin{array}{l}0.18^{*} \\
(3.97)\end{array}$ & $\begin{array}{c}-0.01 * * * \\
(-1.90)\end{array}$ & $\begin{array}{c}0.94 * \\
(44.56)\end{array}$ & $\begin{array}{l}0.13^{*} \\
(4.35)\end{array}$ & $\begin{array}{l}0.93 \\
2.30\end{array}$ \\
\hline SCT & $\begin{array}{c}0.11 \\
(1.21) \\
\end{array}$ & $\begin{array}{l}-0.002 \\
(-0.13) \\
\end{array}$ & $\begin{array}{l}0.93^{*} \\
(66.0)\end{array}$ & $\begin{array}{l}0.12 * \\
(6.73)\end{array}$ & $\begin{array}{l}0.96 \\
2.02\end{array}$ \\
\hline FT & $\begin{array}{l}0.14^{*} \\
(3.64)\end{array}$ & $\begin{array}{l}-0.007 \\
(-1.40)\end{array}$ & $\begin{array}{c}0.99 * \\
(68.63)\end{array}$ & $\begin{array}{l}0.08^{*} \\
(4.39)\end{array}$ & $\begin{array}{l}0.97 \\
2.22 \\
\end{array}$ \\
\hline
\end{tabular}

Notes: 1. Figures in the parentheses are estimated t values.

2. *, **, ***, indicate significant at 1,5 and 10 per cent, respectively.

3. D-W indicates Durbin- Watson 
Own revenues may have been raised by states to their potential in the backdrop of fiscal consolidation to be adhered under their FRBM Acts. Insignificant dummy for committed expenditure and relatively higher coefficient for capital outlay suggest that states should follow fiscal rules for sustaining fiscal consolidation without compromising on quality of expenditure.

A large proportion of state expenditure comprises committed expenditure and other non-plan expenditure on social and economic services which broadly follow a steady growth pattern. Further, the FCs while devolving resources among states emphasise upon tax efforts and fiscal discipline. Therefore, the coefficient of lagged dependent variable is highly statistically significant, indicating stickiness in fiscal indicators on account of persistence of fiscal stance as mentioned earlier. The relatively higher coefficient of lagged dependent variable found in most fiscal indicators in the post-FRBM period confirms greater persistence of fiscal policies across states under fiscal rules (Table 6).

Table 6: Beta Convergence - Panel EGLS Estimation

\begin{tabular}{|l|c|c|c|c|}
\hline \multirow{2}{*}{$\begin{array}{c}\text { Dependent } \\
\text { Variable }\end{array}$} & \multicolumn{4}{|c|}{ 1995-2015 } \\
\cline { 2 - 5 } & Constant & Initial level & $\begin{array}{c}\text { Lagged dependent } \\
\text { variable }\end{array}$ & $\begin{array}{c}\boldsymbol{R}^{2} \\
\text { D-W H Statistic }\end{array}$ \\
\hline TE & $0.18^{*}$ & $-0.01^{* * *}$ & $1.02^{*}$ & 0.98 \\
& $(3.18)$ & $(-1.65)$ & $(173.7)$ & 2.47 \\
\hline CO & $0.26^{*}$ & $-0.02^{* * *}$ & $0.99^{*}$ & 0.91 \\
& $(3.27)$ & $(--1.72)$ & $(69.28)$ & 2.21 \\
\hline RE & $0.17^{*}$ & -0.01 & $1.02^{*}$ & 0.98 \\
& $(3.09)$ & $(-1.48)$ & $(172.03)$ & 2.34 \\
\hline Comm. & $0.19^{*}$ & -0.009 & $0.97 *$ & 0.98 \\
& $(4.51)$ & $(-1.42)$ & $(177.90)$ & 1.97 \\
\hline SSE & $0.14^{*}$ & -0.009 & $1.04 *$ & 0.97 \\
& $(2.58)$ & $(-1.15)$ & $(148.84)$ & 2.18 \\
\hline RR & $0.17^{*}$ & $-0.01^{* * *}$ & $1.03^{*}$ & 0.98 \\
& $(3.70)$ & $(-1.73)$ & $(192.64)$ & 2.48 \\
\hline OTR & $0.20^{*}$ & $-0.01^{*}$ & $1.01^{*}$ & 0.99 \\
& $(6.98)$ & $(-3.30)$ & $(235.43)$ & 2.22 \\
\hline ONTR & $0.23^{*}$ & $-0.02^{* * *}$ & $0.98^{*}$ & 0.89 \\
& $(3.17)$ & $(-1.92)$ & $(62.37)$ & 2.34 \\
\hline ORV & $0.17^{*}$ & $-0.01^{* * *}$ & $1.02^{*}$ & 0.95 \\
& $(3.56)$ & $(-1.63)$ & $(169.72)$ & 2.40 \\
\hline GR & $0.18^{*}$ & $-0.01 * * *$ & $1.02^{*}$ & 0.93 \\
& $(3.81)$ & $(-1.82)$ & $(83.08)$ & 2.37 \\
\hline
\end{tabular}


58 | VISION: Journal of Indian Taxation, Volume 4, Issue 2, Jul-Dec 2017

\begin{tabular}{|c|c|c|c|c|}
\hline SCT & $\begin{array}{c}0.13 \\
(1.38)\end{array}$ & $\begin{array}{l}-0.005 \\
(-0.33)\end{array}$ & $\begin{array}{c}1.01^{*} \\
(115.07)\end{array}$ & $\begin{array}{l}0.90 \\
2.01\end{array}$ \\
\hline FT & $\begin{array}{l}0.13^{*} \\
(3.41)\end{array}$ & $\begin{array}{l}-0.006 \\
(-1.31)\end{array}$ & $\begin{array}{c}1.04^{*} \\
(128.65)\end{array}$ & $\begin{array}{l}0.97 \\
2.32\end{array}$ \\
\hline & \multicolumn{4}{|c|}{$1995-2005$} \\
\hline & Constant & Initial level & $\begin{array}{c}\text { Lagged dependent } \\
\text { variable }\end{array}$ & $\begin{array}{c}R^{2} \\
\text { D-W H Statistic }\end{array}$ \\
\hline $\mathrm{TE}$ & $\begin{array}{l}0.25^{*} \\
(2.96) \\
\end{array}$ & $\begin{array}{c}-0.01 \\
(-1.50) \\
\end{array}$ & $\begin{array}{c}0.92 * \\
(48.83) \\
\end{array}$ & $\begin{array}{l}0.91 \\
2.37\end{array}$ \\
\hline $\mathrm{CO}$ & $\begin{array}{l}0.40 * \\
(3.35) \\
\end{array}$ & $\begin{array}{r}-0.04 * * \\
(-2.38) \\
\end{array}$ & $\begin{array}{c}0.80^{*} \\
(15.48) \\
\end{array}$ & $\begin{array}{l}0.58 \\
1.91 \\
\end{array}$ \\
\hline $\mathrm{RE}$ & $\begin{array}{l}0.25^{*} \\
(2.89)\end{array}$ & $\begin{array}{c}-0.01 \\
(-1.36)\end{array}$ & $\begin{array}{c}0.91 * \\
(51.05)\end{array}$ & $\begin{array}{l}0.92 \\
2.33\end{array}$ \\
\hline Comm. & $\begin{array}{l}0.30 * \\
(4.77)\end{array}$ & $\begin{array}{l}-0.02 * * \\
(-2.09)\end{array}$ & $\begin{array}{c}0.90^{*} \\
(73.50)\end{array}$ & $\begin{array}{l}0.96 \\
2.01\end{array}$ \\
\hline SSE & $\begin{array}{c}0.10 \\
(1.23) \\
\end{array}$ & $\begin{array}{l}0.003 \\
(0.31) \\
\end{array}$ & $\begin{array}{c}0.89^{*} \\
(37.17) \\
\end{array}$ & $\begin{array}{l}0.86 \\
2.09 \\
\end{array}$ \\
\hline $\mathrm{RR}$ & $\begin{array}{l}0.17 * * \\
(2.09) \\
\end{array}$ & $\begin{array}{l}-0.01 \\
(-1.04) \\
\end{array}$ & $\begin{array}{c}0.99 * \\
(45.00) \\
\end{array}$ & $\begin{array}{l}0.90 \\
2.56 \\
\end{array}$ \\
\hline OTR & $\begin{array}{l}0.25 * \\
(6.06)\end{array}$ & $\begin{array}{l}-0.02 * \\
(-3.83)\end{array}$ & $\begin{array}{l}1.02 * \\
(70.6)\end{array}$ & $\begin{array}{l}0.96 \\
2.27\end{array}$ \\
\hline ONTR & $\begin{array}{l}0.24 * \\
(2.33)\end{array}$ & $\begin{array}{l}-0.02 \\
(1.61)\end{array}$ & $\begin{array}{c}0.93^{*} \\
(24.32)\end{array}$ & $\begin{array}{l}0.74 \\
2.17\end{array}$ \\
\hline ORV & $\begin{array}{l}0.21 * \\
(3.04)\end{array}$ & $\begin{array}{c}-0.01 * * * \\
(-1.90)\end{array}$ & $\begin{array}{c}1.02 * \\
(48.90)\end{array}$ & $\begin{array}{l}0.91 \\
2.45\end{array}$ \\
\hline GR & $\begin{array}{c}0.10^{* * * *} \\
(1.88)\end{array}$ & $\begin{array}{c}0.0001 \\
(0.01)\end{array}$ & $\begin{array}{c}0.93 * \\
(25.34)\end{array}$ & $\begin{array}{l}0.74 \\
2.59\end{array}$ \\
\hline SCT & $\begin{array}{l}0.31 * * \\
(2.03)\end{array}$ & $\begin{array}{c}-0.02 \\
(-1.10)\end{array}$ & $\begin{array}{c}0.78^{*} \\
(16.80) \\
\end{array}$ & $\begin{array}{l}0.56 \\
1.88 \\
\end{array}$ \\
\hline \multirow[t]{2}{*}{ FT } & $\begin{array}{l}0.12 * \\
(2.55)\end{array}$ & $\begin{array}{l}-0.003 \\
(-0.57)\end{array}$ & $\begin{array}{c}0.95^{*} \\
(32.43)\end{array}$ & $\begin{array}{l}0.82 \\
2.53\end{array}$ \\
\hline & \multicolumn{4}{|c|}{ 2005-2015 } \\
\hline $\mathrm{TE}$ & $\begin{array}{l}0.34^{*} \\
(4.82)\end{array}$ & $\begin{array}{l}-0.02 * \\
(-3.05)\end{array}$ & $\begin{array}{c}1.01 * \\
(83.32) \\
\end{array}$ & $\begin{array}{l}0.96 \\
2.40\end{array}$ \\
\hline $\mathrm{CO}$ & $\begin{array}{l}0.64 * \\
(5.36)\end{array}$ & $\begin{array}{l}-0.06^{*} \\
(-3.94)\end{array}$ & $\begin{array}{l}0.89 * \\
(29.63)\end{array}$ & $\begin{array}{l}0.83 \\
1.91\end{array}$ \\
\hline $\mathrm{RE}$ & $\begin{array}{l}0.28^{*} \\
(5.47)\end{array}$ & $\begin{array}{l}-0.02^{*} \\
(-3.10)\end{array}$ & $\begin{array}{c}1.02 * \\
(103.1)\end{array}$ & $\begin{array}{l}0.97 \\
2.29\end{array}$ \\
\hline Comm. & $\begin{array}{l}0.14 * \\
(2.72) \\
\end{array}$ & $\begin{array}{l}-0.004 \\
(-0.62)\end{array}$ & $\begin{array}{c}0.99 * \\
(80.84) \\
\end{array}$ & $\begin{array}{l}0.96 \\
2.02\end{array}$ \\
\hline SSE & $\begin{array}{l}0.38 * \\
(4.87) \\
\end{array}$ & $\begin{array}{l}-0.03^{*} \\
(-3.05) \\
\end{array}$ & $\begin{array}{c}1.01 * \\
(76.97) \\
\end{array}$ & $\begin{array}{l}0.96 \\
2.26 \\
\end{array}$ \\
\hline $\mathrm{RR}$ & $\begin{array}{l}0.35^{*} \\
(5.16)\end{array}$ & $\begin{array}{l}-0.02^{*} \\
(-3.29)\end{array}$ & $\begin{array}{c}1.01 * \\
(79.04)\end{array}$ & $\begin{array}{l}0.96 \\
2.13\end{array}$ \\
\hline
\end{tabular}




\begin{tabular}{|l|c|c|c|c|}
\hline OTR & $0.28^{*}$ & $-0.02^{*}$ & $1.00^{*}$ & 0.97 \\
& $(6.19)$ & $(-3.16)$ & $(96.92)$ & 2.12 \\
\hline ONTR & $0.49^{*}$ & $-0.05^{*}$ & $0.88^{*}$ & 0.79 \\
& $(5.17)$ & $(-3.68)$ & $(26.35)$ & 2.05 \\
\hline ORV & $0.36^{*}$ & $-0.03^{*}$ & $0.97^{*}$ & 0.95 \\
& $(5.82)$ & $(-3.59)$ & $(67.48)$ & 2.09 \\
\hline GR & $0.33^{*}$ & $-0.03^{*}$ & $1.03^{*}$ & 0.83 \\
& $(4.09)$ & $(-2.72)$ & $(32.69)$ & 1.96 \\
\hline SCT & 0.09 & 0.01 & $0.92^{*}$ & 0.93 \\
& $(0.99)$ & $(0.92)$ & $(57.48)$ & 2.23 \\
\hline FT & $0.25^{*}$ & $-0.02^{* *}$ & $1.03^{*}$ & 0.91 \\
& $(3.98)$ & $(-2.02)$ & $(49.72)$ & 2.00 \\
\hline
\end{tabular}

Note: 1. Figures in the parentheses are estimated $t$ values.

$2 . *, * *, * * *$, indicate significance at 1,5 and 10 per cent, respectively.

3. D-W indicates Durbin- Watson

As explained in equation 5, beta convergence has also been examined estimating panel unit root test. The panel unit root test of Levin, Lin and Chu (LLC) and Bruiting were performed on demeaned series of fiscal indicators for the period 1995-2015. Results of these tests showed convergence in all fiscal indicators which are broadly consistent with the pattern of beta convergence observed in cross-section OLS and panel data EGLS estimation (Table 7).

Table 7: Panel Unit Root Test (Period: 1995-2015)

\begin{tabular}{|l|c|c|c|c|}
\hline & \multicolumn{2}{|c|}{ Levin, Lin and Chu Unit Root Test } & \multicolumn{2}{c|}{ Breitung Unit Root Test } \\
\hline $\begin{array}{c}\text { Fiscal } \\
\text { Indicator }\end{array}$ & Statistic Value & Probability Value & Statistic Value & $\begin{array}{c}\text { Probability } \\
\text { Value }\end{array}$ \\
\hline TE & -10.81 & 0.000 & -4.30 & 0.000 \\
\hline CO & -12.97 & 0.000 & -5.17 & 0.000 \\
\hline RE & -9.33 & 0.000 & -4.69 & 0.000 \\
\hline Comm & -7.86 & 0.000 & -6.39 & 0.000 \\
\hline SSE & -5.31 & 0.000 & -2.20 & 0.013 \\
\hline RR & -9.25 & 0.000 & -4.91 & 0.000 \\
\hline OTR & -5.23 & 0.000 & -4.25 & 0.000 \\
\hline ONTR & -11.36 & 0.000 & -7.63 & 0.000 \\
\hline ORV & -10.96 & 0.000 & -7.08 & 0.000 \\
\hline GR & -3.78 & 0.000 & -0.73 & 0.232 \\
\hline SCT & -10.57 & 0.000 & -11.31 & 0.000 \\
\hline FT & -5.71 & 0.000 & -3.00 & 0.001 \\
\hline
\end{tabular}




\subsection{Conclusion}

This paper examines sigma and beta convergence for fiscal indicators of 25 states in India. The empirical findings reveal sigma and beta convergence in most of the revenue and expenditure indicators used in the study. Results on beta convergence showed that the speed of convergence was the highest in respect of capital outlay. The expenditure convergence seems to have been contributed by convergence in states' own revenues and fiscal transfers. Convergence in most of the fiscal indicators with beta convergence happening at a higher speed in some indicators such as capital outlay and social sector expenditure during the post-FRBM period is indicative of the contribution of policy initiatives undertaken by the states. The role of FRBM Act in the growth of revenues and expenditures (except committed expenditure) with relatively higher coefficient for capital outlay, own non-tax revenue and fiscal transfers suggest that states should continue to follow fiscal rules for fiscal consolidation without compromising on its quality. Convergence in per capita tax revenues and expenditures across states has implications for achieving regional balance in economic development.

\section{Endnotes}

1. For example per capita own tax revenue of Bihar, Odisha and Tripura (Rs.1629, Rs. 3514 and Rs. 2728, respectively) in 2012-13 was much lower than Gujarat, Sikkim and Tamil Nadu (Rs.8944, Rs. 6990 and Rs. 10462, respectively).

2. There are differences across states in terms of share of various tax and non-tax revenues in total revenues as well as share of expenditure on various services in total expenditure.

3. During 1990-91 to 2014-15, average own tax revenue-GSDP ratio was 8.7 per cent in Karnataka, 4.7 per cent in West Bengal and 1.3 per cent in Mizoram. Similarly, large variations exist across states in terms of revenue expenditure-GSDP ratios; 22.2 per cent in Bihar, 34.3 per cent in Manipur and 11.1 per cent in Maharashtra.

4. Per capita GSDP of Odisha, Bihar, Sikkim and Tripura was relatively lower in 2004-05 but their CAGR of GSDP during 2004-15 increased at higher rate than Kerala, Maharashtra and Punjab (the relatively high income states in 2004-05).

5. Per capita GSDP at constant prices (2004-05).

6. Cherodian et al. (2013) found no unconditional convergence but weak conditional convergence when controlled for other variables such as population growth and share of agriculture. Bandyopadhyay (2011) found income disparities across states had declined in 1960s but increased during 1970s to 1990s. Rangarajan et al. (2014) found no absolute convergence but catching up by some low income states.

7. The concepts of sigma and beta convergence have been explained in section on data and methodology. 
8. Chhattisgarh, Jharkhand and Uttarakhand are excluded due to non-availability of consistent data points for the full period covered in this study i.e. 1995-2015.

9. The Debt Swap Scheme (DSS) operated during 2002-03 to 2004-05 enabled the states to prepay Central Government loans having interest rate of over 13 per cent by raising lower cost debt from the market or through small savings schemes. Outstanding Central Government loans amounting to Rs. 1.02 lakh crore were prepaid by the states during this period which benefited them in lowering their interest burden.

10. Data on fiscal indicators for 2013-14 and 2014-15 relate to revised estimates and budget estimates, respectively.

11. Population data of latest year for some states were not available with CSO and therefore these data were calculated based on average growth of previous three years.

12. Committed expenditure includes interest payments, pension and administrative services expenditure of states.

13. Includes expenditure on social services, food storage \& warehousing and rural development classified under 'revenue expenditure', 'capital outlay' and 'loans and advances'.

14. With the inclusion of lagged dependent variable and a dummy in the panel data equation, one can treat the convergence process as conditional beta convergence. However, unlike studies on conditional beta convergence, this paper controls only persistence in policy stance (lagged dependent variable) and the fiscal rules (state-wise dummies for FRBM) and does not control for any structural/real variable affecting directly the state fiscal indicators- revenue or expenditure (like GSDP, population, share of agriculture, literacy ratio etc.) and thus it may not be appropriate to consider it as conditional beta convergence.

15. In this paper, capital outlay in the post-FRBM period is found to have diverged as per sigma convergence method even though it shows beta convergence indicating higher growth recorded by states having initial high level of capital outlay.

16. In 1995-96, per capita own non-tax revenue of Haryana and Punjab was higher at Rs.1,188 and Rs. 804, respectively, than that of Kerala and Uttar Pradesh (Rs. 176 and Rs. 164, respectively). However, the CAGR of own non-tax revenue during 1995-96 to 2014-15 was higher in Kerala and Uttar Pradesh (13 and 9 per cent, respectively) than that of Haryana and Punjab (3 and 1 per cent, respectively).

17. Capital outlay-GDP ratio of all states at consolidated level increased from 1.8 per cent in 2003-04 to 2.5 per cent in 2008-09.

18. Per capita capital outlay of Bihar and Odisha was lower in 2005-06 (Rs.231 and Rs.266, respectively) but they recorded higher CAGR of 15 per cent and 17 per cent, respectively during 2005-06 to 2014-15 as compared to 5 per cent and 1 per cent of Maharashtra and Punjab, respectively, which were having relatively higher capital outlay during 2005-06 (Rs.968 and Rs.573, respectively). The co-efficient of variation in capital outlay increased to 0.98 in 2014-15 from 0.96 in 2005-06 which indicates increased disparities in 2014-15 though there was evidence of beta convergence during this period. 
62 |VISION: Journal of Indian Taxation, Volume 4, Issue 2, Jul-Dec 2017

\section{References}

Bandyopadhyay, S. (2011). Convergence clubs in incomes across Indian states: Is there evidence of a neighbours effect? Retrieved from http://personal.lse.ac.uk/BANDYOPS/ CCELrev.pdf.

Barro, R. J. \& X. Sala-I-Martin (1991). Convergence across states and regions. Brookings Papers on Economic Activity. 22(1), 107-182.

Baumol, W. J. (1986). Productivity growth, convergence, and welfare: What the longrun data show. The American Economic Review, 76(5), 1072-1085.

Bhargava, A., L. Franzini, \& W. Narendranathan (1982). Serial correlation and the fixed effects model. Review of Economic Studies, 49(4) 533-549.

Breitung, J. (2000). The local power of some unit root tests for panel data. In B. Baltagi (ed.). Advances in Econometrics, 15: Nonstationary Panels, Panel Cointegration, and Dynamic Panels, pp. 161-178, Amsterdam: JAI Press.

Cherodian, R. \& A. P. Thirlwall (2013). Regional disparities in per capita income in India: Convergence or divergence? University of Kent, School of Economics Discussion Papers, August 2013. Retrieved from https://www.kent.ac.uk/economics/documents/ research/papers/2013/1313.pdf.

Coughlin, C., Garrett, T. A. \& Hernandez-Murillo, R. (2006). Spatial dependence in models of state Fiscal policy convergence. Federal Reserve Bank of St. Louis Working Paper, 001B.

Evans, P. \& Karras, G. (1996). Convergence revisited. Journal of Monetary Economics, 37(2), 249-265.

Garg, S. (2015). Spatial convergence in public expenditure across Indian states: implication of federal transfers. IGIDR Working Paper No. 028.

Government of India (2013). Press note on poverty estimates, 2011-12. Planning Commission. Retrieved from http://planningcommission.nic.in/news/pre_pov2307.pdf. 
Government of India (2011). India Human Development Report 2011: Towards social inclusion. Institute of Applied Manpower Research, Planning Commission.

Islam, N. (1995). Growth empirics: A panel data approach. The Quarterly Journal of Economics, 110(4), 1127-110.

Jain, R. \& Kumar, P. (2013). Size of government expenditure multipliers in India: A structural VAR analysis. RBI Working Paper No 7.

Levin, A., C. Lin, and C. J. Chu (2002). Unit root tests in panel data: Asymptotic and finite sample properties. Journal of Econometrics, 108(1), 1-24.

Mohanty, B. K. (2011). Convergence in public expenditure and public revenue across indian states: implications for sustainable economic growth. Asian Journal of Empirical Research, 1(1), 14-24.

Mukhopadhyay, D. \& Sarkar, N. (2014). Convergence of foodgrains production across Indian states: A study with panel data. Indian Statistical Institute, Discussion Paper, No.3.

Rangarajan, C., Kaul, P. I. \& Vibeesh, E.M. (2014). Convergence have the lower income states 'caught up. ICRA Bulletin Money and Finance, February, 43-56.

Saruc, N. T., Sagbas, I. \& Cigerci, I. (2007). Convergence in public expenditures and revenues across the Turkish provinces. Paper presented in 63rd congress of the International Institute of Public Finance, August 27-30, 2007.

Scully, G. W. (1991). How state and local taxes affect economic growth. National Center for Policy Analysis (NCPA) Policy Report, No. 161.

Sethi, A.S. \& Kaur, B. (2012). Are Indian states converging on public expenditure? An empirical evidence. The Journal of Income and Wealth, 34(3), 73-88.

Tiebout, C. M. (1956). A pure theory of local expenditures. Journal of Political Economy. 64(5), 416-424. 